\title{
Microchip Electrophoretic Analysis of Phaseolin Patterns and Its Comparison with Currently Used SDS-PAGE Techniques
}

\author{
Emanuel Marques da Silva • Teresa Maria Marques dos \\ Santos $\cdot$ José Filipe Teixeira Ganança $\cdot$ \\ Jan Jacek Slaski • Miguel Â. A. Pinheiro de Carvalho
}

Received: 14 February 2013/Revised: 31 May 2013/Accepted: 1 July 2013/Published online: 13 July 2013

(C) Springer-Verlag Berlin Heidelberg 2013

\begin{abstract}
The goal of this work was to compare reproducibility of phaseolin patterns of common bean obtained by two electrophoretic protein separation techniques including the conventional SDS-PAGE and an automated chip electrophoresis system. Five standard cultivars of common bean provided by the United States Department of Agriculture (Beltsville, Maryland) that represented five phaseolin types, $\mathrm{T}$ (Tendergreen), $\mathrm{C}$ (Contender) and $\mathrm{S}$ (Sanilac), B (Boyaca) and $\mathrm{P}$ (Pampa), were used in this study. Comparison of the phaseolin patterns revealed that the chip-on-a-lab electrophoresis provided a good reproducibility. The phaseolin polymorphism included four to seven polypeptides typical for the pattern composition of the T, C and S types. The polymorphism of the B and $\mathrm{P}$ patterns was also established. Phaseolin polypeptides separated by the microchip electrophoresis exhibited differences with respect to the molecular weights and electrophoretic mobility as compared to the SDS-PAGE technique. This phenomenon could be attributed to the absence of a solid separation phase in the microchip electrophoresis. Moreover, this technique has potential to substantially accelerate screening of large bean germplasm collections since it allows for the accurate analysis of the higher number of individual plants within accessions than the conventional, tedious and time consuming SDS-PAGE method.
\end{abstract}

E. M. da Silva $(\bowtie)$. T. M. M. dos Santos .

J. F. T. Ganança · J. J. Slaski · M. Â. A. P. de Carvalho Banco de Germoplasma ISOPlexis, Universidade da Madeira, 9020-105 Funchal, Portugal

e-mail: emasi12008@gmail.com

\section{J. J. Slaski}

Bioresource Technologies, Alberta Innovates, Technology Futures Vegreville, Vegreville, AB T9C 1T4, Canada
Keywords Microchip electrophoresis - SDS-PAGE · Technique validation $\cdot$ Protein pattern $\cdot$ Phaseolin

\section{Introduction}

Common bean (Phaseolus vulgaris L.) is an important staple food providing protein, fiber, minerals and vitamins [1]. Recently, this crop has also gained increasing attention as functional food [2]. The distinct geographical distribution of beans wild relatives raise the questions of where common bean domestication occurred and what is the gene pool origin of modern crop cultivars. According to [3], beans were probably domesticated in Mexico from where they were subsequently disseminated across the Latin America. Later, [4] established the existence of two major crop gene pools, the Mesoamerican and the Andean, and one or two smaller gene pools in the northern Andean. Two major gene pools are commonly distinguished with the use of morphological and biochemical markers [5]. These pools can be detected at different ratios in modern crop cultivars, depending on their place of origin. Employing the 1D-SDS-PAGE and 2D-IEF-SDS-PAGE techniques [6] revealed the existence of three phaseolin types associated with "Sanilac", "Tendergreen" and "Contender" cultivars, later named the S, T and C types, respectively. More recently, the $\mathrm{H}$ and $\mathrm{A}$ phaseolin types have been identified in wild and cultivated forms, associated with the Peruvian landraces "Huevo de Huanchaco" and "Ayachucho" [7], and the B type occurring among the Mesoamerican landraces [8]. Later, the $\mathrm{H}$ and $\mathrm{B}$ types have been linked to Pampa and Boyaca cultivars [9].

A relationship between the phaseolin type, seed type and the geographical origin has been established. Cultivars with the $\mathrm{T}, \mathrm{C}, \mathrm{H}$, and A phaseolin patterns had larger seeds than 
cultivars with the $\mathrm{S}$ and $\mathrm{B}$ types $[8,10]$. Cultivars with small seeds and the $\mathrm{S}$ and $\mathrm{B}$ phaseolin types are of Mesoamerican origin, while the cultivars with large seeds and the $\mathrm{T}, \mathrm{C}, \mathrm{H}$ or A types originated from the Andes. The $\mathrm{S}$ and $\mathrm{T}$ types prevail in the Central America and the Andean South America, respectively, while the $\mathrm{C}$ type appears to be an intermediary type resulting from crosses of the major types [8]. Phaseolin analysis is commonly used to determine the geographical origin [11] and the structure and variability of common bean gene pools [12]. Therefore, polymorphism of the phaseolin patterns has been used to determine the phytogeographical origin of bean cultivars $[9,13]$. It was also successfully applied for characterization of genetic resources and used as a marker in the selection of plant materials [14] and breeding [12, 15].

Phaseolin is a glycoprotein [16] that remains the major fraction of seed storage protein. It represents main seed quality trait [17], coded by a single complex loci composed of 6-9 genes [18, 19] expressed for different polypeptide subunits $[6,20]$. The observed polymorphism of phaseolins is the result of micro-heterogeneity of their subunits [21] determined by a relation between the homology $(60 \%)$ of amino acid sequences [22], the presence of a structural domain contributing to an eighth of the subunits size [23] and different levels of protein glycosylation and amino acid substitutions [24]. The phenotype of phaseolin molecular weight and isoelectric changes resulting from genotypic divergence are useful tools to analyze evolutionary relationships among the phaseolin types and cultivars [9]. [15, 20, 25] analyzed phaseolin patterns using the SDS-PAGE. They identified three polypeptides with molecular weights of 54-50.5, 47 and $43 \mathrm{kD}$. Using the same technique, [16] identified four polypeptides ranging from 54.0 to $43.0 \mathrm{kD}$, and [6] provided a full description of the $\mathrm{S}, \mathrm{T}$ and $\mathrm{C}$ phaseolin types. Based on the molecular weights and apparent fractions, genetic control of six polypeptides were found in Sanilac, four in Tendergreen and seven in Contender.

The polyacrylamide gel electrophoresis in the presence of sodium dodecyl sulphate (SDS-PAGE) is a traditional method for screening of protein polymorphism and determination of the phaseolin pattern. However, it is a slow, cumbersome and not quantitative procedure. The microfluidic chip technology based on the capillary electrophoresis that allows an automatic and immediate quantitative interpretation offers new opportunities for a quick protein analysis in a great number of samples [26]. However, to apply the chip-on-a-lab electrophoresis to the phaseolin analyses it is necessary to demonstrate its reproducibility, as well as to establish an association with standard patterns of the SDS-PAGE electrophoresis.

The purpose of this study was to compare the microchip electrophoresis with the SDS-PAGE technique in the analysis of phaseolin pattern using standard cultivars for $\mathrm{S}$, $\mathrm{T}, \mathrm{C}, \mathrm{B}$ and $\mathrm{H}$ phaseolin types and validate the results obtained by the new electrophoresis technique.

\section{Materials and Methods}

Five standard bean cultivars provided by the USDA (Beltsville, Maryland) genebank were used to obtain phaseolin patterns of the S, T, C, B and $\mathrm{H}$ types. Phaseolins were extracted individually from ten seeds per cultivar. Cotyledons without teguments and embryos have been reduced to flour, and each flour sample was used for phaseolin extraction. Protein extraction was performed according to $[15,27]$, with modifications, using $0.2 \mathrm{~g}$ of dried bean flour per sample and $1 \mathrm{~mL}$ of extraction solution composed of $0.25 \mathrm{M}$ ascorbic acid, $\mathrm{pH} 2.4$ and $0.5 \mathrm{M}$ $\mathrm{NaCl}$. Protein content in the extract was determined using the Bradford method [28], before the samples preparation for electrophoresis analysis. The samples for SDS-PAGE and the chip electrophoresis were prepared by mixing equal volumes $(500 \mu \mathrm{L})$ of protein extract and denaturing solution with $0.625 \mathrm{M}$ Tris- $\mathrm{HCl}, \mathrm{pH} 6.8 ; 2 \mathrm{mM}$ ethylenediamine tetraacetic acid (EDTA), $2 \%(\mathrm{w} / \mathrm{v})$ SDS, $40 \%(\mathrm{w} / \mathrm{v})$ sucrose and $1 \%(\mathrm{v} / \mathrm{v}) 2$-mercaptoethanol. The resulting mixture was heated to $100{ }^{\circ} \mathrm{C}$ for $5 \mathrm{~min}$ and centrifuged at 13,000 rpm for $15 \mathrm{~min}$. The electrophoresis was carried out in $15 \%$ polyacrylamide gels, prepared with PlusOne Acrylamide PAGE, $40 \%$, from GE Healthcare, ref. 17-1303-01, according to [29] with modifications [30]. Protein fractions were separated in a vertical gel in the electrophoretic system Hoefer SE 600. To obtain an accurate and reproducible phaseolin pattern, $10.8 \mu \mathrm{g}$ of protein per sample were used. The polypeptide weights were determined by their relative electrophoretic mobility in relation to molecular markers provided by Amersham Low Molecular Weight Calibration Kit for SDS Electrophoresis, ref. 17-0446-01. After protein separation, the gels were fixed in a solution with methanol $(40 \%)$ and acid acetic $(10 \%)$ and stained in Coomassie solution with $0.1 \%$ Brillant Blue R, $40 \%$ methanol and $10 \%$ acetic acid.

The same samples with an equivalent amount of protein were analysed using the chip-on-a-lab technique. Protein extracts for the electrophoretic separation were prepared using the Experion Pro260 analysis kit. The Experion automated electrophoresis system, Caliper Life Sciences, Inc. and Bio-Rad Laboratories are capable of combining the microfluidic separation technology with the sensitive fluorescent detection of proteins, automatically performing the separation, staining, discoloration and imaging of ten individual samples, with band detection and data analysis in $30 \mathrm{~min}$. The Experion automatically displayed the 
electrophoretic results in a form of an elution profile (peak) and a virtual gel (simulated views).

SDS-PAGE stained gels were scanned with the Image Scanner from Amersham Biosciences, model PowerLook 1120 USG, series 01145582. The electrophoregram profiles were analyzed for determination of phaseolin molecular weight using the Fingerprinting II Informatix ${ }^{\mathrm{TM}}$ Software, version 3.0 (BioRad).

The molecular weights of phaseolin bands were determined by the Experion or fingerprinting software as logarithmic dependence of marker molecular weight to relative electrophoretic mobility, and expressed in $\mathrm{kD}$. The bands mean values and the experimental deviation were calculated using the values obtained for ten individual seeds. The electrophoretic profiles represent ten individual seed samples. Phaseolin profile for each individual sample was repeated at least three times, and checked for the reproducibility and accuracy.

\section{Results and Discussion}

Seeds of standard cultivars-Boyaca, Sanilac, Tendergreen, Contender, Pampa - used in this study represent five known phaseolin types, namely the $\mathrm{B}, \mathrm{S}, \mathrm{T}, \mathrm{C}$ and $\mathrm{H}$ types, associated with the centers of crop domestication $[6,8,19]$. Phaseolins subjected to the electrophoretic analyses were obtained through a selective extraction according to $[15$, 27]. A comparison of the individual patterns of 10 seeds per cultivar obtained by two electrophoretic techniques revealed a high level of consistency of their composition. The regression analysis of the weight variation of individual polypeptides between the SDS-PAGE and the Experion produced values of $r$ of 0.854 for Boyaca, 0.852 for Sanilac, 0.947 for Contender, 0.853 for Tendergreen and 0.968 for Pampa. The variation in the polypeptides molecular weights was used to establish their mean values, standard deviation and to analyze accuracy of the method. The electrophoretic results, including composition, number and molecular weight of polypeptides in the phaseolin patterns calculated with assistance of the Experion and Fingerprinting software, as well as the phaseolin type classified according to [6,9] are summarized (Table 1). The representative electrophoregrams for each standard cultivar obtained by both the microchip and the SDSPAGE techniques are presented in Fig. 1. In general, the microchip electrophoresis generated phaseolin patterns (Fig. 1a) are similar to those obtained by the SDS-PAGE (Fig. 1b). However, some differences in their composition, polypeptide electrophoretic mobility and weight were distinguished. The individual phaseolin polypeptides detected by the microchip electrophoresis were validated by the elution profiles and peak areas generated by the Experion software (Fig. 2). The polypeptides of the phaseolin pattern obtained through SDS-PAGE were captured and their molecular weights were determined by the Fingerprinting II Informatix ${ }^{\mathrm{TM}}$ Software (Bio-Rad), using a normalized reference system for calculation of molecular weight in the electrophoresis separations. The reproducibility of microchip electrophoresis was tested by the statistical comparison of five independent runs for each phaseolin type and through the separation of the same samples in different positions of the microchip (Fig. 3). The statistical comparison was based on a combination of peak height and the apparent molecular weights of polypeptides and showed a relative standard deviation less than $2 \%$ (data not shown).

We found that Sanilac and Boyaca exhibited the highest polymorphism, with six and five polypeptides in the phaseolin pattern, respectively. The Andean types-Tendergreen, Contender and Pampa-show four bands in the SDS-PAGE, whereas the microchip electrophoresis detected six (Tendergreen) and five (Contender) polypeptides in the phaseolin pattern. The phaseolin patterns of SDSPAGE (Fig. 1b; Table 1) exhibit slight discrepancies in the number and molecular weights of phaseolin subunits, when compared with the early quantitative results. We detected between four and six phaseolin subunits for different cultivars, which is majorly in accord with [6] findings for the S, C and T types. However, [15, 20, 25] detected only three and [16] four phaseolin subunits using the SDS-PAGE. Our preparations of protein from the seeds of Sanilac have revealed six phaseolin subunits ranging from 47.7 to $42.6 \mathrm{kD}$, similarly to [6] who also reported six subunits ranging from 49 to $45 \mathrm{kD}$. Tendergreen had four subunits ranging from 50.9 to $42.1 \mathrm{kD}$, which corresponds to four subunits of $51-45.5 \mathrm{kD}$ reported by [6]. However, we found four subunits ranging from 50.9 to $43.5 \mathrm{kD}$ in Contender, while [6] identified seven subunits (51-45 kD) in this cultivar. The number of subunits detected for Boyaca was 5, ranging from 49.6 to $41.8 \mathrm{kD}$ and for Pampa 4 subunits, ranging from 50.9 to $41.2 \mathrm{kD}$. [6] do not provide data for the phaseolin pattern of these types. One can conclude that our results on SDS-PAGE phaseolin pattern fit and satisfactorily reproduced previously published data on the phaseolin polymorphism. Minor inconsistencies could be attributed to the polypeptide modifications introduced by mutations [24] or to the differences in experimental conditions, such as reagents, quantity of protein used in extraction, gel concentration and the 1D-SDSPAGE accuracy or sensibility of the fingerprinting software used to acquire bands' presence and calculate their molecular weights.

The results of the microchip capillary electrophoresis are not strictly corresponding to the outcomes of the SDSPAGE electrophoresis with respect to the number and molecular size of the extracted polypeptides (Table 1; 
Table 1 Comparison of phaseolin type and molecular weights $(\mathrm{kD})$ on the SDS-PAGE and chip electrophoresis patterns for Boyaca, Sanilac, Contender, Tendergreen and Pampa

Fig. 1 Phaseolin pattern of standard varieties of common bean: a chip electrophoresis, b SDS-PAGE. Lines: Ladder (L), Boyaca (1), Contender (2), Pampa (3), Sanilac (4), Tendergreen (5)

\begin{tabular}{|c|c|c|c|c|c|}
\hline Samples & Phaseolin type & SDS-PAGE $(\mathrm{kD})$ & $\begin{array}{l}\text { Microchip } \\
\text { electrophoresis (kD) }\end{array}$ & Variation $(\mathrm{kD})$ & Variation $(\%)$ \\
\hline \multirow[t]{5}{*}{ Boyaca } & \multirow[t]{5}{*}{ B } & $49.61 \pm 0.44$ & $63.41 \pm 0.84$ & 13.80 & 27.8 \\
\hline & & $44.85 \pm 0.44$ & $61.14 \pm 0.80$ & 16.29 & 36.3 \\
\hline & & $43.32 \pm 0.41$ & $53.14 \pm 0.72$ & 9.82 & 22.0 \\
\hline & & $42.94 \pm 1.94$ & $49.88 \pm 0.60$ & 6.94 & 16.2 \\
\hline & & $41.81 \pm 0.35$ & $42.29 \pm 1.75$ & 0.48 & 0.5 \\
\hline \multirow[t]{6}{*}{ Sanilac } & \multirow[t]{6}{*}{$\mathrm{S}$} & $47.74 \pm 0.18$ & $63.3 \pm 1.42$ & 15.56 & 32.6 \\
\hline & & $47.00 \pm 0.15$ & $60.64 \pm 1.27$ & 13.64 & 29.0 \\
\hline & & $45.63 \pm 0.17$ & $52.51 \pm 1.03$ & 6.88 & 15.1 \\
\hline & & $44.56 \pm 0.18$ & $49.62 \pm 0.86$ & 5.06 & 11.4 \\
\hline & & $43.79 \pm 1.51$ & $45.7 \pm 2.79$ & 1.91 & 4.4 \\
\hline & & $42.55 \pm 0.18$ & $42.69 \pm 3.15$ & 0.14 & 0.3 \\
\hline \multirow[t]{5}{*}{ Contender } & \multirow[t]{5}{*}{$\mathrm{C}$} & $50.92 \pm 0.29$ & $65.60 \pm 1.11$ & 14.68 & 28.8 \\
\hline & & $49.10 \pm 0.26$ & $60.57 \pm 0.97$ & 11.47 & 22.9 \\
\hline & & $48.03 \pm 0.24$ & $56.09 \pm 0.84$ & 8.06 & 16.8 \\
\hline & & $43.59 \pm 0.22$ & $50.19 \pm 0.66$ & 6.60 & 15.1 \\
\hline & & - & $40.97 \pm 1.59$ & - & - \\
\hline \multirow[t]{6}{*}{ Tendergreen } & \multirow[t]{6}{*}{$\mathrm{T}$} & $50.93 \pm 0.38$ & $64.58 \pm 0.90$ & 5.65 & 26.8 \\
\hline & & $48.27 \pm 0.30$ & $59.53 \pm 0.85$ & 11.26 & 23.3 \\
\hline & & $46.11 \pm 0.31$ & $55.14 \pm 0.72$ & 9.03 & 19.6 \\
\hline & & $42.10 \pm 0.21$ & $49.62 \pm 0.60$ & 7.52 & 17.9 \\
\hline & & - & $44.54 \pm 0.89$ & - & - \\
\hline & & - & $41.10 \pm 1.42$ & - & - \\
\hline \multirow[t]{4}{*}{ Pampa } & \multirow[t]{4}{*}{$\mathrm{H}$} & $50.93 \pm 0.30$ & $60.50 \pm 0.53$ & 9.57 & 18.8 \\
\hline & & $49.08 \pm 0.32$ & $52.66 \pm 0.32$ & 3.58 & 7.3 \\
\hline & & $43.26 \pm 1.60$ & $49.55 \pm 0.32$ & 6.29 & 14.5 \\
\hline & & $41.19 \pm 0.26$ & $41.72 \pm 3.07$ & 0.53 & 1.3 \\
\hline
\end{tabular}

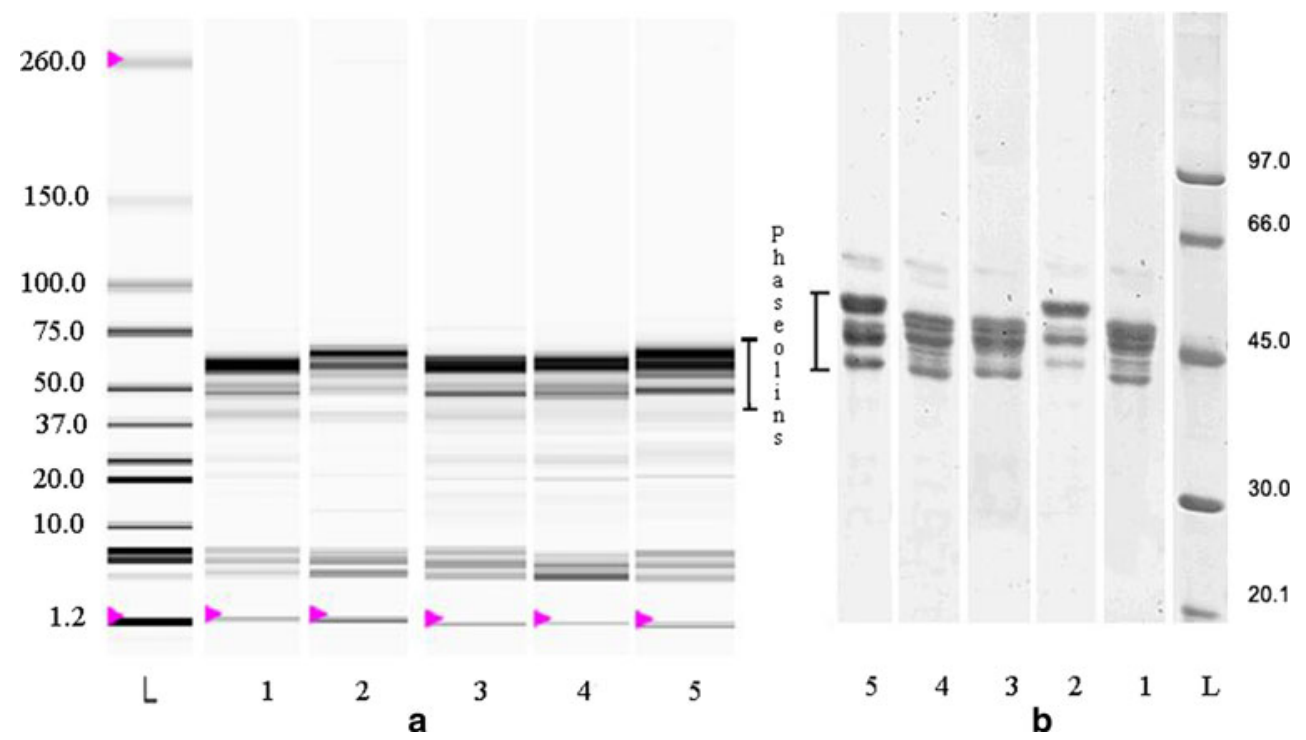

Figs. 1, 2). An average variation of polypeptide molecular weight ranging from 16.29 to $0.14 \mathrm{kD}$ was observed (Table 1). In addition, we detected three additional phaseolin subunits including two in the Tendergreen, and one in the Contender phaseolin pattern, making the first pattern more polymorphic, while the latter more 


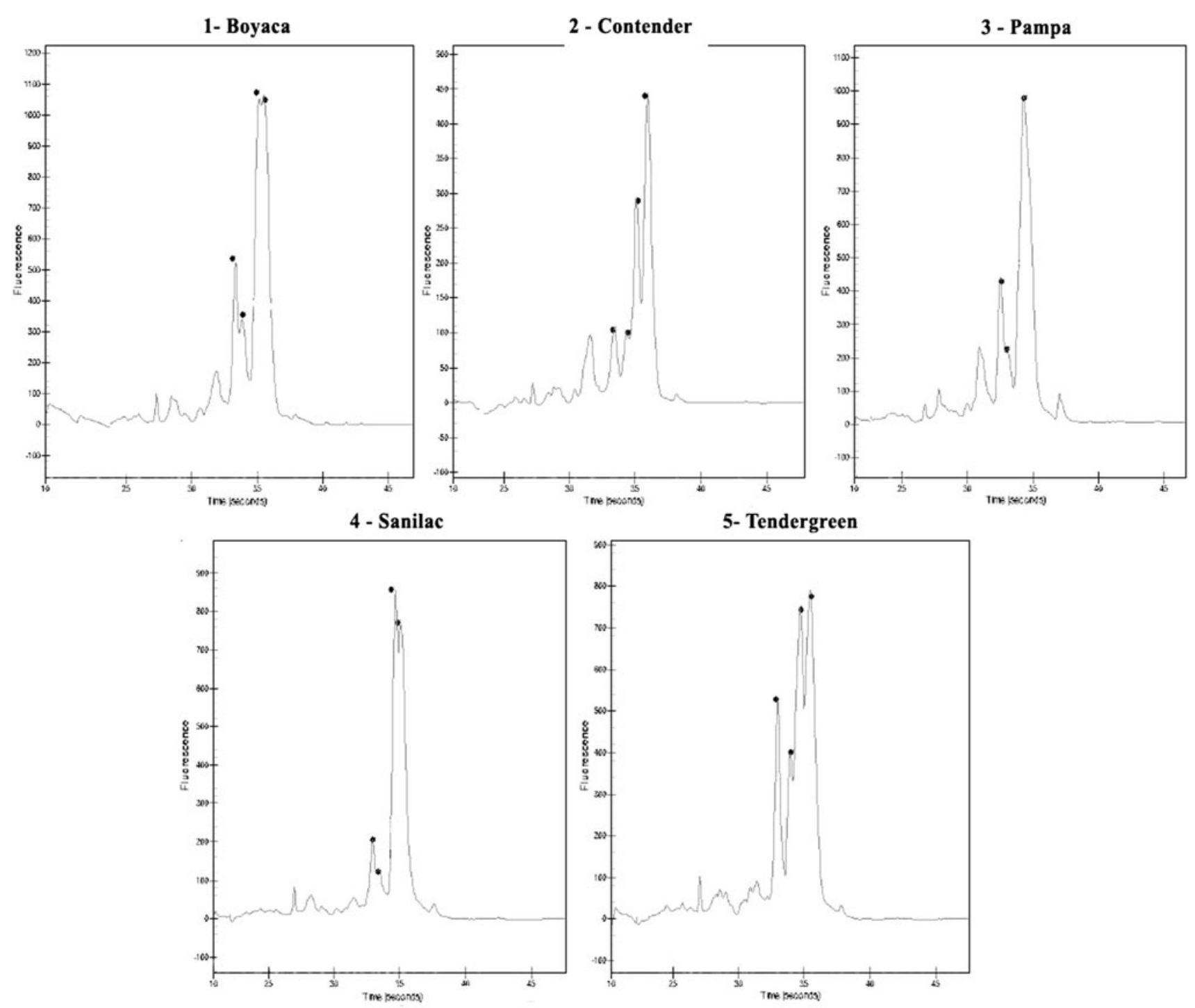

Fig. 2 Elution profiles of phaseolin from seeds of standard cultivars of common bean, chip electrophoresis: Boyaca (1), Contender (2), Pampa (3), Sanilac (4), Tendergreen (5)

resembling the polymorphism described [6] for the $\mathrm{T}$ and $\mathrm{C}$ types. These discrepancies may be due to different conditions of protein separation in the microchip electrophoresis, when compared to the SDS-PAGE. The solid separation phase, e.a. polyacrylamide gel could create an additional sieve effect that limits free migration of the protein in a combination with the effects of gel pore resistance and molecular size and shape [31]. Conversely, the microchip electrophoresis does not involve solid separation phase, hence, the polypeptides mobility depends on molecule sizes and presumably on the compounding effects of protein conformation and shape, together with differences in the specific interaction of proteins with the capillary channels $[26,32]$. These interactions are conditioned by the effects of sieving polymeric solution of the dye-labeled phaseolin-SDS complexes, which are reduced by the SDS dilution below its critical micelle concentration before protein detection [33]. The detection of additional phaseolin bands results from the higher sensitivity of the microchip technology, which can detect as low as $10 \mathrm{ng}$ of protein per band [34], because of the strongly reduction of background due to molecules bound to SDS micelles [33]. Similar variation in molecular weights of high-molecular-weight glutenin subunits has been previously reported by [32] who argued that the microchip electrophoresis provides a good pattern reproducibility in the screening of wheat glutenins. The ability of this method to distinguish rice [35] and wheat varieties [26, 36] has already been reported. Our data confirmed reproducibility of the phaseolin pattern for common bean 
Fig. 3 Evaluation of the reproducibility of microchip electrophoresis through the separation of the same Sanilac (positions 1-5) and Contender (positions 6-10) samples

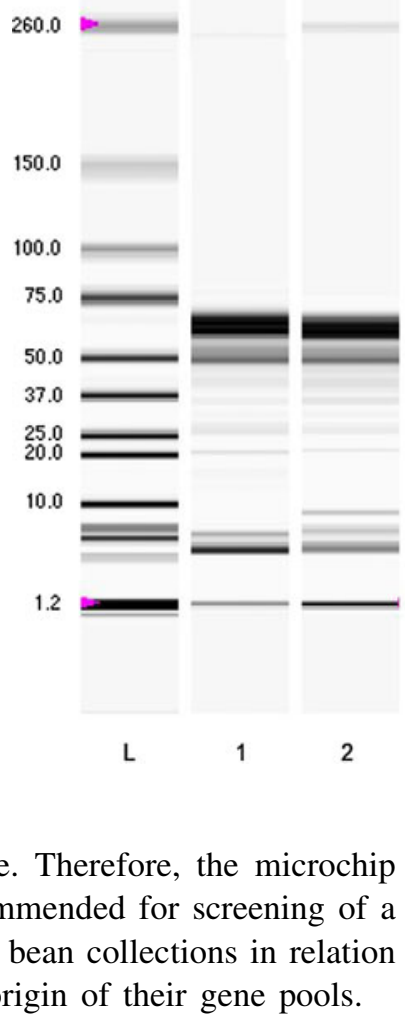

using the microchip technique. Therefore, the microchip electrophoresis could be recommended for screening of a large number of accessions in bean collections in relation to the possible geographical origin of their gene pools.

\section{Conclusions}

The results obtained by the two techniques were characterized by good comparability. The analysis of molecular weights using the microchip electrophoresis seems to be a very reliable technology for establishing the phaseolin patterns of bean accessions that could be used in the phytogeographical or biodiversity studies. At the same time, the microchip electrophoresis is more accurate and permits detection of protein bands with protein content and perform their immediate quantification avoiding limitations of the SDS-PAGE electrophoresis. The greatest advantage of the commercial Experion Pro260 analysis kit and the Experion automated electrophoresis system is the automatic interpretation of the results, which saves time and labor and avoids exposure to harmful chemicals required for the SDS-PAGE.

Acknowledgments At the USDA-United States Department of Agriculture for ceding species Phaseolus vulgaris L. standards used in this study.

\section{References}

1. Ying H, Zhiqiang C, Larry IH, Stuart BK, Raymond PG, Ross MW (2006) J Agric Food Chem 54:9254-9261

2. Broughton WJ, Hernandez G, Blair M, Beebe S, Gepts P, Vanderleyden J (2003) Plant Soil 252:55-128

3. Gentry HS (1969) Econ Bot 23:55-69

4. Koenig R, Gepts P (1989) Theor Appl Genet 78:809-817

5. Singh SP (2001) Crop Sci 41:1659-1675

6. Bliss FA, Brown JWS (1982) Qual Plant Plant Foods Itum Nutr 31:269-279

7. Rodiño AP, Monteagudo AB, Santalla M (2001a) Methodology for electrophoretic analysis of phaseolin. In: Jacobsen H-J, Múzquiz M, Hassa A (eds) Handbook on common bean related laboratory methods. Pontevedra, Spain

8. Gepts P, Bliss FA (1986) Econ Bot 40(4):469-478

9. Rodiño AP, Santalla M, Montero I, Casquero PA, De Ron AM (2001) Genet Resour Crop Evol 48:409-417

10. Gepts P, Osborn TC, Rashka K, Bliss FA (1986) Econ Bot 40(4):451-468

11. Gepts P, Bliss FA (1988) Econ Bot 42:86-104

12. Logozzo G, Donnoli R, Macaluso L, Papa R, Knupffer H, Zeuli PS (2007) Genet Resour Crop Evol 54:1763-1779

13. Igrejas G, Carnide V, Pereira P, Mesquita F, Guedes-Pinto H (2009) Plant Genet Resour: Charact Util 7(3):230-236

14. Kelly JD, Miklas PN (1999) Marker assisted selection. In: Singh SP (ed) Common bean improvement in the twenty first century. Kluwer Academic publishers, Dordrecht, The Netherlands

15. Romero J, Sun SM, McLeester RC, Bliss FA, Hall TC (1975) Plant Physiol 56:776-779

16. Sturm A, Van Kuik JA, Vliegenthart JFG, Chrispeels MJ (1987) J Biol Chem 262(28):13392-13403

17. Bliss FA, Brown JWS (1983) Plant Breed Rev 1:59-102 
18. Brown JWS, Bliss FA, Hall TC (1981) Theor Appl Genet 60:251-259

19. Brown JWS, Ma Y, Bliss FA, Hall TC (1981) Theor Appl Genet 59:83-88

20. Osborn TC (1988) Crit Rev Plant Sci 7:93-116

21. Brown JWS, Bliss FA, Hall TC (1980) Plant Physiol 66:838-840

22. Ma Y, Bliss FA, Hall TC (1980) Plant Physiol 66:897-902

23. Suzuki E, Van Donkelaar A, Varghese JN, Lilley GG, Blagrove RJ, Colman PM (1983) J Biol Chem 258(4):2634-2636

24. Paaren HE, Slightom JL, Hall TC, Inglis AS, Blagrove RJ (1987) Phytochemistry 26:335-343

25. Hall TC, McLeester RC, Bliss FA (1977) Plant Physiol 56:776-777

26. Bradová J, Matějová E (2008) Chromatographia 67:S83-S88

27. Sun S, Hall T (1975) J Agric Food Chem 23(2):184-189

28. Bradford M (1976) Anal Biochem 72:248

29. Laemmli UK (1970) Nature 22:680-685

30. Ma Y, Bliss FA (1978) Crop Sci 18:432-437
31. Garfin DE (2003) Gel electrophoresis of proteins. In: Davey J, Lord M (eds) Essential cell biology. Vol. 1. Cell structure, a practical approach. Oxford University Press, Oxford

32. Uthayakumaran S, Listiohadi Y, Baratta M, Batey IL, Wrigley CW (2006) J Cereal Sci 44:34-39

33. Bousse L, Mouradian S, Minalla A, Yee H, Williams K, Dubrow R (2001) Anal Chem 73:1207-1212

34. Zhu K, Nguyen M, Strong W, Whitman-Guliaev C (2010) Technical notes Bio-RAD Bulletin. 5299 Rev B

35. Siriamornpun S, Suttajit M, Uthayakumaran S, Wrigley CW (2004) Identification of Thai rice varieties using capillary electrophoresis. In: Black CK, Panozzo JF, Rebetzke GJ (eds) Cereals 2004 proceedings of the 54th Australia Cereal Chemistry Conference and the 11th Wheat breeders' Assembly. Royal Australian Chemical institute, Melbourne

36. Uthayakumaran S, Batey IL, Wrigley CW (2005) J Cereal Sci 41:371-374 